\title{
DIET OF THE OILFISH Ruvettus pretiosus (PERCIFORMES: GEMPYLIDAE) IN THE SAINT PETER AND SAINT PAUL ARCHIPELAGO, BRAZIL
}

\author{
Danielle de Lima Viana*, Mariana Travassos Tolotti, Mariana Porto, Rodolfo Jorge Vale de Araújo, \\ Teodoro Vaske Júnior and Fabio Hissa Vieira Hazin
}

Universidade Federal de Pernambuco - Departamento de Pesca

(Av. Dom Manuel de Medeiros, S/N, 52171-030 Jaboatão dos Guararapes, PE, Brasil)

*Corresponding author: vianadl@yahoo.com

\begin{abstract}
Feeding aspects of the oilfish, Ruvettus pretiosus, were studied based on 360 stomachs of both male and female specimens caught off the Saint Peter and Saint Paul Archipelago. The total length of the specimens ranged from $52.4 \mathrm{~cm}$ to $189.0 \mathrm{~cm}$. Of the 360 stomachs examined, 135 presented some food and 225 were empty. Thirty-four taxa were identified, represented by 16 fish, 17 cephalopods and 1 crustacean. The stabilization of the food items richness was attained at 35 food items and 104 stomachs, approximately. A remarkable predation upon the flying fish Cheilopogon cyanopterus was observed around SPSPA, directly related to the main reproductive period of this species in the area. The oilfish's food spectrum shows that the species feeds on a wide vertical range in the water column, catching prey items at the surface or in shallow waters, as well as epi-mesopelagic fish, in addition to mesopelagic cephalopods.
\end{abstract}

\section{RESUMO}

Aspectos alimentares do peixe-prego, Ruvettus pretiosus, foram estudados com base nos estômagos de 360 espécimes, de ambos os sexos, capturados nos arredores do Arquipélago de São Pedro e São Paulo. Todos os exemplares foram capturados com linha de mão. O comprimento total dos exemplares variou de 52,4 cm a 189,0 cm. Dos 360 estômagos examinados, 135 apresentaram algum alimento e 225 estavam vazios. Trinta e quatro táxons foram identificados, representados por 16 peixes, 17 cefalópodes e um crustáceo. A estabilização da riqueza dos itens alimentares foi obtida com 35 itens e 104 estômagos. Uma predação notável sobre o peixe-voador Cheilopogon cyanopterus foi observada nas adjacências do ASPSP, diretamente relacionada com o principal período reprodutivo dessa espécie na área. $\mathrm{O}$ espectro alimentar do peixe-prego mostra que a espécie se alimenta em uma ampla faixa vertical na coluna d'agua, capturando desde presas de superfície ou águas rasas, a peixes epi-mesopelágicos, além de cefalópodes mesopelágicos.

Descriptors: Perciformes, Benthopelagic species, Stomach content, hand line, Island.

Descritores: Perciformes, Espécie bentopelagica, Conteúdo estomacal, linha de mão, Ilha.

\section{INTRODUCTION}

The oilfish Ruvettus pretiosus Cocco, 1829 is an oceanic benthopelagic species that occurs in tropical, subtropical and temperate waters of the Atlantic, Pacific and Indian oceans (NAKAMURA; PARIN, 1993), including the Mediterranean Sea (UYENO et al., 1983; NAKAMURA; PARIN, 1993; BETTOSO; DULCIC, 1999; ELBARAASI et al., 2007). It attains a total length of approximately $300 \mathrm{~cm}$ (NAKAMURA; PARIN, 1993) and more than $50 \mathrm{~kg}$ (PAKHORUKOV; BOLTACHEV, 2001), usually being found on the continental slope and in oceanic areas from 100 m (UYENO et al., 1983; CERVIGÓN et al., 1992; NAKAMURA; PARIN, 1993; FIGUEIREDO; MENEZES, 2000) to about $1,500 \mathrm{~m}$ depth (NAKAMURA, 1995). It usually migrates to the surface at night, feeding on squid, bony fish and crustaceans (NAKAMURA, 1995; PAKHORUKOV; BOLTACHEV 2001; ELBARAASI et al., 2007). Present on the entire Brazilian coast, the oilfish is regularly caught by the tuna longline fleet based on the states of Rio Grande do Norte and Pernambuco (northeast Brazil). In the vicinity of the Saint Peter and Saint Paul Archipelago (SPSPA), the species is caught by hand line, mainly during the dry season (July to September), when catches of the main target species, yellowfin tuna, (Thunnus albacares), are substantially reduced (VIANA et al., 2008).

Fisheries activity targeting $R$. pretiosus is only undertaken in a few marine areas of the Atlantic, mainly by small scale fishing fleets using hand lines (CASTRO et al., 2000). Nevertheless, oilfish specimens also appear as an incidental by-catch in numerous drifting surface longline fisheries 
targeting tuna and swordfish (CASTRO et al., 2000; MEJUTO et al., 2002). The oilfish has a high commercial value, being much appreciated on the domestic market (WEIDNER; AROCHA, 1999). In Brazil and depending on its texture and flavor, its meat has been widely requested by Japanese restaurants, which sell it as sushi and sashimi under the name of white-fish or white-marlin.

Although the oilfish is regularly caught by fishing boats operating along the Brazilian coast, published information about the biology of $R$. pretiosus is very scarce. Vasilakopoulos et al. (2011) examined the dietary preferences and reproductive biology of about 50 specimens in the eastern Mediterranean showing that the most numerous and frequently occurring prey items were benthopelagic fish, followed by cephalopods, and that the spawning is expected to occur during mid and late summer. According to Nakamura (1995) and Pakhorukov and Boltachev (2001), it feeds on squid, bony fish and crustaceans. Curiously, most citations in the literature refer exclusively to the high lipid content of its meat (COX; REID, 1932; NEVENZEL et al., 1965; SATO; TSUCHIYA, 1969; OCHIAI et al., 1984; RUIZGUTIERREZ et al., 1997; SHADBOLT et al., 2002; LING et al., 2008).

A thorough knowledge of the species' diet is important to enable one to understand the oilfish's aggregation behavior in oceanic areas as well as in the vicinity of islands and offshore banks (VASKE JR. et al., 2003). In this context, the stomach contents of the oilfish were analyzed in this study, with regard to food composition in terms of weight, size, number and frequency of occurrence of prey categories, aiming at generating specific information about the feeding habits, particularly in the vicinity of the Saint Peter and Saint Paul Archipelago.

\section{Material and Methods}

The 360 specimens examined were captured in the Saint Peter and Saint Paul Archipelago (SPSPA), a small group of rocky islands located near the Mid-Atlantic Ridge, about $100 \mathrm{~km}$ north of the equator $\left(00^{\circ} 55 \mathrm{~N} ; 029^{\circ} 20 \mathrm{~W}\right)$ (CAMPOS et al., 2009) (Fig. 1). All the specimens were caught by hand line at depths ranging from 50 to $250 \mathrm{~m}$, at night, using chunks of flying fish (C. cyanopterus) caught on the spot, as bait. The stomachs were collected during 28 scientific expeditions, undertaken between June 2008 and July 2011, with an average duration of 15 days each. After boarding, all fish were identified and measured, for total (TL) and standard (SL) lengths. They were eviscerated for the collection of the stomachs, which were then frozen intact for later analysis in the laboratory.

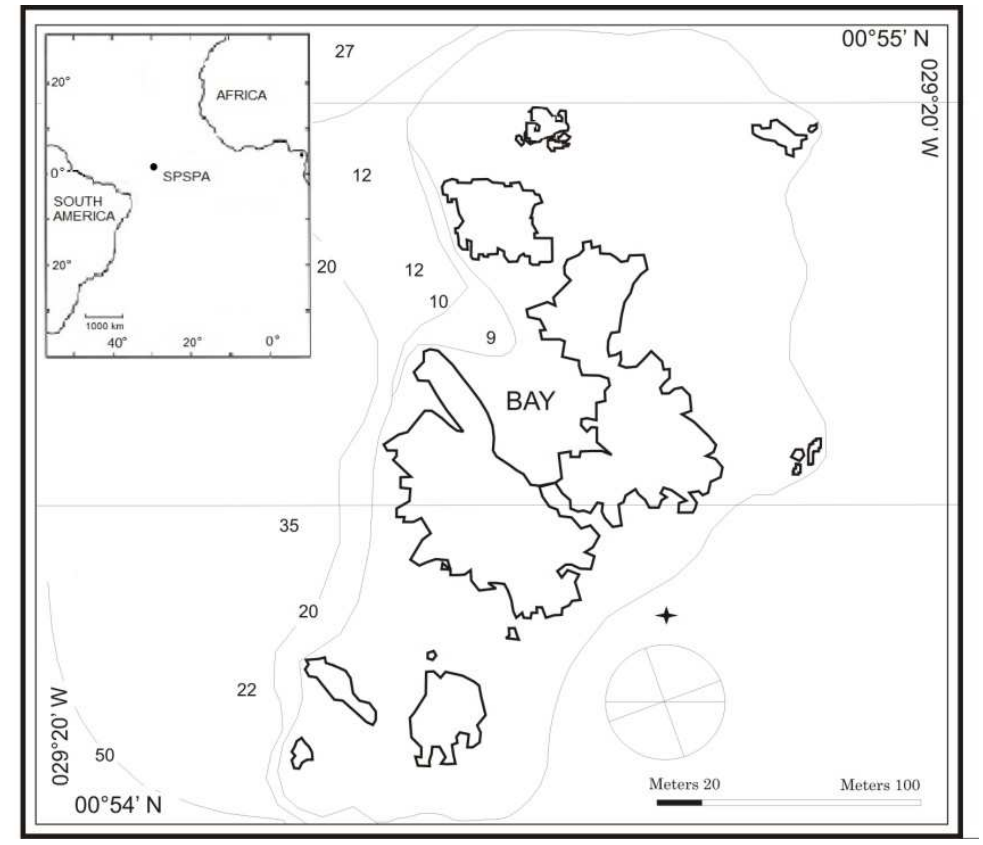

Fig. 1. Saint Peter and Saint Paul Archipelago, Brazil. 
All materials removed from the stomachs were regarded as stomach content. Each food category was named a food item and each food item unit was called a prey. The number of units of each food item, its length (mantle length for cephalopods) in centimeters and weight in grams were recorded for each stomach. The bait used was not counted in the total sum of prey items since it was not part of the natural diet.

Each prey item was identified to the lowest taxonomic category possible. The percentages in number $(\% \mathrm{~N})$, wet weight in grams $(\% \mathrm{P})$ and frequency of occurrence ( $\%$ FO) of each food item was recorded and used to calculate the Index of Relative Importance (IRI) (PINKAS et al., 1971), in order to rank their order of importance: IRI $=\% \mathrm{FO} x$ (\% $\mathrm{N}+\% \mathrm{P})$. In the case of cephalopod beaks, only their numerical influence per species was considered, since they are chitinous non-digestible structures, small and very light. A curve of prey species richness was drawn to verify whether the number of stomachs analyzed was sufficient and representative of the food spectrum. An Index of Stomach Repletion was determined according to the scale proposed by Vaske Jr. (2003), as follows: $0=$ empty, $1=$ almost empty $/ 25 \%$ full, $2=$ half $/ 50 \%$ full, $3=$ almost full $/ 75 \%$ full and $4=$ full $/ 100 \%$ complete.

The degree of prey digestion was also determined according to the scale proposed by Vaske Jr. et al. (2004), as follows: I - non-digested prey (ND); II - starting digestion (SD), with loss of parts of skin, and scales of fishes and squids, and of carapaces of crustaceans; III - advanced digestion (AD), with loss of fins and muscular parts; IV - complete digestion (CD), only remains of muscles, bones, carapaces, and cephalopod beaks.

\section{RESULTS}

Of the 360 individuals examined, 340 were female $(94.4 \%)$ and 20 male $(5.6 \%)$. The overall male: female ratio was 1:17. The total length of the specimens ranged from 52.4 to $189.0 \mathrm{~cm}$, with modes between $110-130 \mathrm{~cm}$ for both males and females (Fig. 2).

Of the 360 stomachs collected, 225 were empty $(62.5 \%)$ and 135 had some content $(37.5 \%)$. Of the stomachs with contents, $8.6 \%$ were almost empty ( $25 \%$ full), $16.9 \%$ were half full (50\% complete), $8.3 \%$ were almost full (75\% full) and $4.1 \%$ were full (100\% full) (Fig. 3). Bait items were found in 17 stomachs, representing $12.5 \%$ of total stomachs with some content. Ten stomachs $(7.1 \%)$ presented nondigested prey (I), 19 (13.7\%) were starting digestion (II), $44(31.7 \%)$ were in advanced digestion (III) and
$66(47.5 \%)$ showed nearly complete digestion with prey reduced to just parts of muscles, bones and shells.

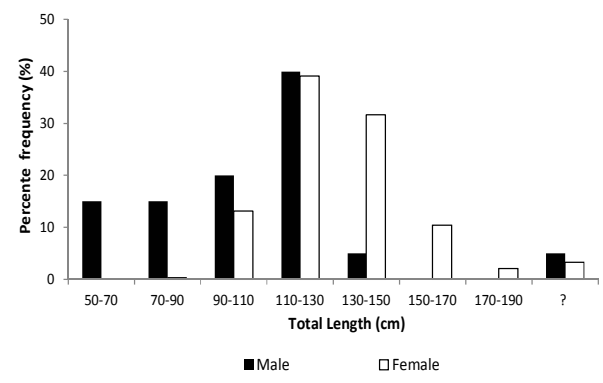

Fig. 2. Size distribution for both sexes of Ruvettus pretiosus caught in the SPSPA $(n=360)$.

Thirty-four taxa (1 infraclass, 2 orders, 13 families, 7 genera and 11 species) were identified in the stomach contents, including 16 taxa of fish, 17 of cephalopods and one crustacean (Table 1).

Table 1. Proportion of organisms found in the stomachs of oilfish, Ruvettus pretiosus, caught in the SPSPA, by forage category.

\begin{tabular}{lll}
\hline \hline \multicolumn{1}{c}{ Forage category } & \multicolumn{1}{c}{ \% taxa } & $\mathbf{n}^{\circ}$ of stomachs \\
\cline { 1 - 1 } Teleosteans & 66.4 & 101 \\
Cephalopods & 32.9 & 50 \\
Crustaceans & 0.7 & 1 \\
Total & $\mathbf{1 0 0 . 0}$ & $\mathbf{1 5 2}$
\end{tabular}

The major groups were: C. cyanopterus, unidentified teleosteans, and cephalopods of the family Opistotheutidae $64.8 \%$ of the total number (Table 2). Foreign objects thrown from vessels, such as polystyrene, nylon strings, steel hooks, bones and bovine meat, were also found. According to the IRI ranking the two main items in the oilfish's diet were the fish species Cheilopogon cyanopterus.

Specimens of Cheilopogon cyanopterus are likely included in these unidentified species as well, thus making their IRI even higher. Caranx lugubris, and Elagatis bipinnulata occurred on only one occasion. Cephalopods of the families Opistotheutidae, Octopodidae and Cranchiidae were found in $53.0 \%$ of stomachs, with $71.0 \%$ representing only the family Opistotheutidae. At the species level, the following cephalopods were found: Stenoteuthis pteropus, Ocythoe tuberculata, Ancistrocheirus lesueur, Enoploteuthis leptura and Octopus insularis. 
Table 2. Percentages in number, weight, and frequency of occurrence of food items of Ruvettus pretiosus, in the Saint Peter and Saint Paul Archipelago. IRI - Index of Relative Importance, ranging from 1 to 5 in order of importance (OI).

\begin{tabular}{|c|c|c|c|c|c|c|c|c|}
\hline PREY ITEMS & $\mathbf{N}$ & $\% \mathbf{N}$ & $\mathbf{W}$ & $\% \mathrm{~W}$ & FO & \%FO & IRI & OI \\
\hline DECAPODA & 1 & 0.45 & 2.81 & 0.0 & 1 & 0.59 & 0 & \\
\hline \multicolumn{9}{|l|}{ TELEOSTEI } \\
\hline MURAENIDAE & 1 & 0.45 & 100 & 0.6 & 1 & 0.59 & 1 & \\
\hline Brama caribbea Mead, 1972 & 2 & 0.90 & 153.07 & 1.0 & 2 & 1.18 & 2 & \\
\hline Elagatis bipinnulata Quoy and Gaimard, 1825 & 1 & 0.45 & 210.83 & 1.3 & 1 & 0.59 & 1 & \\
\hline Caranx lugubris Poey, 1860 & 1 & 0.45 & 441 & 2.8 & 1 & 0.59 & 2 & \\
\hline CHIASMODONTIDAE & 1 & 0.45 & 0.73 & 0.0 & 1 & 0.59 & 0 & \\
\hline Coryphaena sp. & 1 & 0.45 & 794 & 5.0 & 1 & 0.59 & 3 & \\
\hline Cheilopogon cyanopterus Valenciennes, 1847 & 57 & 25.68 & 8854.7 & 55.2 & 47 & 27.81 & 1204 & 1 \\
\hline FAMILY GEMPYLIDAE & 1 & 0.45 & 14 & 0.1 & 1 & 0.59 & 0 & \\
\hline Gempylus serpens Cuvier, 1829 & 8 & 3.60 & 2600.3 & 16.2 & 2 & 1.18 & 23 & \\
\hline Promethichthys prometheus Cuvier, 1832 & 2 & 0.90 & 1145.5 & 7.1 & 2 & 1.18 & 10 & \\
\hline SCORPAENIDAE & 1 & 0.45 & 156.2 & 1.0 & 1 & 0.59 & 1 & \\
\hline STOMIIFORMES & 3 & 1.35 & 64.5 & 0.4 & 2 & 1.18 & 2 & \\
\hline Balistes sp. & 1 & 0.45 & 43.7 & 0.3 & 1 & 0.59 & 0 & \\
\hline TETRAODONTIDAE & 1 & 0.45 & 136.5 & 0.9 & 1 & 0.59 & 1 & \\
\hline Lagocephalus sp. & 1 & 0.45 & 29.9 & 0.2 & 1 & 0.59 & 0 & \\
\hline UNIDENTIFIED TELEOSTEI & 49 & 22.07 & 2221.3 & 13.9 & 36 & 21.30 & 765 & 2 \\
\hline \multicolumn{9}{|l|}{ MOLLUSCA } \\
\hline \multicolumn{9}{|l|}{ CLASS CEPHALOPODA } \\
\hline Chiroteuthis sp. (beak) & 3 & 1.80 & & & 3 & 1.78 & 2 & \\
\hline Chiroteuthis sp. & 1 & 0.45 & 13.53 & 0.1 & 1 & 0.59 & 0 & \\
\hline Enoploteuthis sp. (beak) & 2 & 0.90 & & & 2 & 1. 18 & 1 & \\
\hline Enoploteuthis leptura Leach, 1817 & 3 & 1.35 & 95.12 & 0.6 & 3 & 1.78 & 3 & \\
\hline HISTIOTEUTHIDAE (beak) & 4 & 1.80 & & & 4 & 2.37 & 4 & \\
\hline Histioteuthis sp. & 1 & 0.45 & 4.58 & & 1 & 0.59 & 0 & \\
\hline MASTIGOTEUTHIDAE & 1 & 0.45 & 150 & 0.9 & 1 & 0.59 & 1 & \\
\hline OMMASTREPHIDAE (beak) & 1 & 0.45 & & & 1 & 0.59 & 0 & \\
\hline OMMASTREPHIDAE & 1 & 0.45 & 555 & 3.5 & 1 & 0.59 & 2 & \\
\hline Sthenoteuthis pteropus Steenstrup, 1855 (beak) & 1 & 0.45 & & & 1 & 0.59 & 0 & \\
\hline ONYCHOTEUTHIDAE (beak) & 1 & 0.45 & & & 1 & 0.59 & 0 & \\
\hline Ancistrocheirus lesueurii Férussac and Orbigny, 1839 & 1 & 0.45 & & & 1 & 0.59 & 0 & \\
\hline CRANCHIIDAE (beak) & 5 & 2.25 & & & 4 & 2.37 & 5 & \\
\hline GONATIDAE & 1 & 0.45 & 558 & 3.5 & 1 & 0.59 & 2 & \\
\hline OCTOPODIDAE (beak) & 5 & 2.25 & & & 3 & 1.78 & 4 & \\
\hline Octopus insularis Leite and Haimovici, 2008 (beak) & 1 & 0.45 & & & 1 & 0.59 & 0 & \\
\hline Octopoteuthis sp. & 2 & 0.90 & & & 1 & 0.59 & 0.00 & \\
\hline OPISTHOTEUTHIDAE (beak) & 38 & 17.12 & & 0.0 & 19 & 11.24 & 192 & 3 \\
\hline Ocythoe tuberculata Rafinesque, 1814. (beak) & 1 & 0.47 & & & 1 & 0.59 & 0 & \\
\hline UNIDENTIFIED CEPHALOPOD & 8 & 3.60 & & & 8 & 4.73 & 17 & \\
\hline UNIDENTIFIED ITEMS & 8 & 3.60 & 395.8 & 2.5 & 8 & 4.73 & 29 & \\
\hline Total & 222 & 100 & 16.030 & 100 & 169 & 100 & & \\
\hline
\end{tabular}




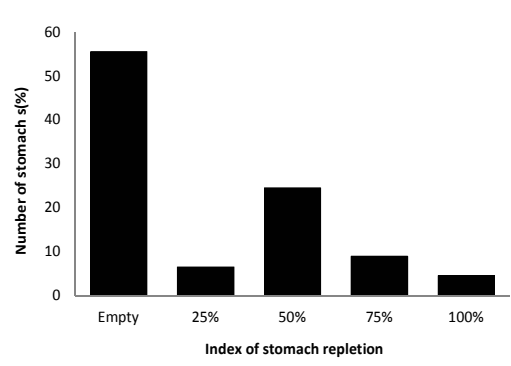

Fig. 3. Index of stomach repletion of Ruvettus pretiosus in the Saint Peter and Saint Paul Archipelago $(n=360)$.

The stabilization of the food item richness was attained at 35 food items and 104 stomachs, approximately, which means that the number of individuals sampled was sufficient to obtain the feeding spectra of food items (Fig. 4).

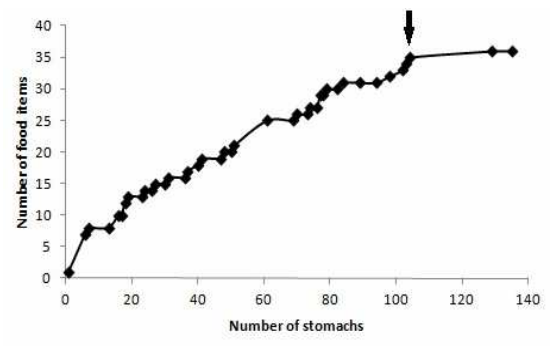

Fig. 4. Food item diversity curve of Ruvettus pretiosus in the Saint Peter and Saint Paul Archipelago. Arrow indicates the stabilization point.

The length of prey ranged from 5.9 to 56.0 $\mathrm{cm}$, with most of them lying between 20.0 and 30.0 $\mathrm{cm}$, and being represented mainly by $C$. cyanopterus as well as by cephalopods of the family Ommastrephidae. Classes above $45.0 \mathrm{~cm}$ were represented exclusively by the teleosts: Coryphaena sp., Elagatis bipinnulata and Gempylus serpens (Fig. 5). There was no correlation between body length of prey and predator, with both large and small predator preying both large and small prey (Fig. 6).

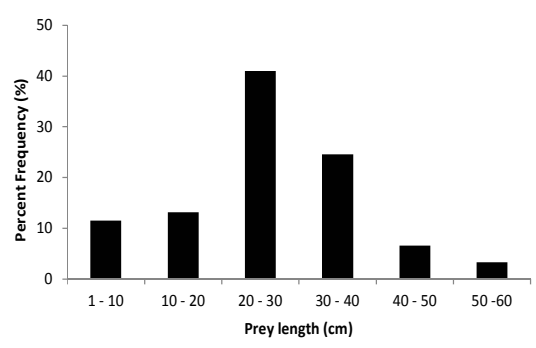

Fig. 5. Prey size distribution of Ruvettus pretiosus in the Saint Peter and Saint Paul Archipelago $(\mathrm{n}=61)$.

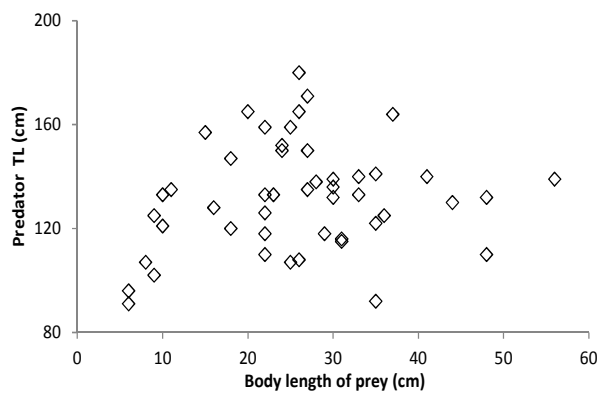

Fig. 6. Relationship between body length of prey and predator size in the Saint Peter and Saint Paul Archipelago $(\mathrm{n}=48)$.

\section{Discussion}

The sex ratio observed in the present study (1:17), with a great predominance of females, approximated to that encountered by Vasilakopoulos et al. (2011) in the eastern Mediterranean (1:8.4). The authors suggested that the predominance of females in their sample could be due to stratification in relation to migration and habitat use. Lorenzo and Pajuelo (1999) observed a vertical space portioning among the sexes, with Promethichthys prometheus (same family) females predominating in shallower depths. The number of stomachs analyzed seemed to be sufficient to provide a reasonable understanding of the diet of the oilfish, as shown by the diversity curve. Besides contributing to knowledge of the prey items ingested by the oilfish in the SPSPA, however, the study of the stomach contents of deep water species, such as the oilfish, also permits the detection of species not easily accessible by conventional fishing gear, because of the great depths they reach. The high number of flying fish and teleosteans in the diet shows a probable association of the species with the Archipelago, like that of other predators in the area (VASKE JR. et al., 2003; VASKE JR. et al., 2006; LESSA; VASKE JR., 2009).

The food spectrum of the oilfish indicates that the species feeds on a wide vertical range in the water column, catching prey such as $C$. cyanopterus, Caranx lugubris and Elagatis bipinnulata at the surface or in shallow waters, as well as epimesopelagic fish, such as Brama caribbea, $P$. prometeus, Stomiiformes, and mesopelagic cephalopods, like those represented in the families Histioteuthidae, Mastigoteuthidae and Chiroteuthidae. The constant presence of remains of Opisthoteuthidae octopus, mainly as isolated beaks, indicates a preference for this prey, which, although not identified to the species level, is known to live close to the bottom. This could, however, mean that either the 
oilfish raids near the bottom to catch octopus, or that this octopus species may occasionally rise in the water column. Nevertheless, in a survey on the cephalopod species of SPSPA based on the stomach contents of other fish species, the family Opisthoteuthidae did not occur in any of the tunas and wahoos examined (ANDRADE et al., 2008; VASKE JR. et al. 2003), suggesting that oilfish predation on Opisthoteuthidae may indeed be related to a closer association with the bottom.

The large amplitude of prey size may be more closely related to prey availability than to some kind of diet preference or limitation due to the size of the oilfish's mouth. This hypothesis seems to be confirmed by the fact that the length distribution of the main prey available in the region, the flying fish Cheilopogon cyanopterus (LESSA; VASKE JR., 2009), matches the length frequency distribution of the specimens preyed on by the oilfish.

The fact that larger squids (Ommastrephidae and Ancistrocheirus lesueuri) have been found only with the back of the body without the presence of beaks in the stomach may indicate a likely strategy of the oilfish's grabbing these preys on the run, a situation in which the squid's head is more protected than its tail.

The high proportion of empty stomachs reported in this paper $(62.5 \%)$ is superior to the values typically observed for other large pelagic fish, such as the yellowfin tuna (Thunnus albacares) and the wahoo (Acanthocybium solandri), studied in the same region (the Saint Peter and Saint Paul Archipelago) (VASKE JR. et al., 2003). However, it is very close to the frequency of empty stomachs observed in a study on the same species in the Mediterranean Sea, where Vasilakopoulos et al. (2011) recorded $63.3 \%$ of empty stomachs. Still, according to these authors, this result probably occurs due to the less active lifestyle of $R$. pretiosus, which may even be related to the significant amount of energy stored by the high lipid concentration in their tissues (NEVENZEL et al., 1965; RUIZ-GUTTIEREZ et al., 1997; NICHOLS et al., 2001).

The number of taxa identified in this study is higher than those found by other studies conducted in the same region. Vaske Jr. et al. (2003), for instance, reported 25 food items for Thunnus albacares and Acanthocybium solandri, and 27 food items for Elagatis bipinnulata (VASKE JR. et al., 2006), whereas 35 items were identified in this study of the oilfish. This is probably due to the fact that the oilfish commonly inhabits depths down to $1,500 \mathrm{~m}$ (NAKAMURA, 1995). According to Pakhorukov and Boltachev (2001), adult individuals dwell near the land during the daylight hours, mainly at a distance of 0.1 to $7 \mathrm{~m}$, preferring bottom sites with even surfaces at depths from 240 to $1,160 \mathrm{~m}$, but mostly from 400 to
$600 \mathrm{~m}$. At night, however, part of the population can perform vertical migrations for feeding, rising into the epipelagial zone to depths of less than $60 \mathrm{~m}$ from the surface (PAKHORUKOV and BOLTACHEV, 2001). Fishing for oilfish only occurs during the night, at a time, coincidently, when the main prey present in the region, the flying fish, C. cyanopterus, also aggregates around the Archipelago.

Vasilakopoulos et al. (2011) also speculated that the individuals performing these nocturnal vertical trophic migrations - which are highly energetically demanding since the nocturnal feeding habitats might be several hundred meters above the diurnal habitats - are generally those that were unable to meet their dietary needs in the benthopelagic zone.

When comparing the oilfish's preferences for teleosteans with those of other large predators already studied in that region (Thunnus albacares and Acanthocybium solandri) (VASKE JR. et al., 2003), it may be observed that $C$. cyanopterus is the only item common to them. The oilfish's feeding habits are closer to those of the wahoo, which also preys on Gempylus serpens, Carangidae and Balistidae. As for cephalopods, only four taxa of the 17 recorded in this study were observed by Vaske Jr. et al. (2003) in the same region as Thunnus albacares and Acanthocybium solandri.

$R$. pretiosus specimens in the SPSPA are mostly ichthyophagous, consuming also cephalopods but only rarely crustaceans, as was also found by Vasilakopoulos et al.(2011), similarly to many other gempylid species (NAKAMURA; PARIN, 1993). Among the fish, C. cyanopterus was the most numerous species. Vasilakopoulos et al. (2011) included chondricthyan eggs among the prey items of $R$. pretiosus; no such eggs were, however, identified in the stomachs analysed in the present study.

In the same way for the oilfish, Vaske Jr. et al. (2003) also recorded high predation pressure on the flying fish $C$. cyanopterus by Thunnus albacares and Acanthocybium solandri in the area surrounding the SPSPA, which means that this flying fish species is the most important food item for these three predators in the vicinity of the SPSPA, and thus the main reason for their aggregation in the area, especially between January and April during the main breeding period of C. cyanopterus.

\section{ACKNOWLEDGEMENTS}

The present study was made possible by funding from the Conselho Nacional de Desenvolvimento Científico e Tecnológico (CNPq) and the Secretaria da Comissão Interministerial para os Recursos do Mar (SECIRM). 


\section{REFERENCES}

ANDRADE, L. C. A. Diversidade de cefalópodes e o seu papel no nichotrófico de seus principais predadores nos Arquipélagos de Fernando de Noronha e São Pedro e São Paulo. 2008. 51p. Dissertação (Mestrado) Univ. Fed. do Rio Grande do Norte, UFRN, Rio Grande do Norte, 2008.

BETTOSO, N.; DULCIC, J. First record of the oilfish Ruvettus pretiosus (Pisces: Gempylidae) in the northern Adriatic Sea. J. Mar. Biol. Ass. UK., v.79, p.1145-1146. 1999.

CAMPOS, T. F. C.; PETTA, A. R.; THEYE, T.; SICHEL, S E.; SIMÕES, L. S. A.; SRIVASTAVA, N. K.; MOTOKI, A.; VIRGENS NETO, J.; ANDRADE, F. G. G. Posição ímpar do Arquipélago de São Pedro e São Paulo na diversidade geológica da Terra. In: VIANA, D.; HAZIN, F.; CARVAlHO, M. A. (Ed.). O Arquipélago de São Pedro e São Paulo: 10 anos de Estação Científica. v.1, p. 54-73. 2009. Available at: <https://www.mar.mil.br/secirm/publicacao/arquipe.pdf> Accessed: January 2011

CASTRO, J.; DE LA SERNA, J. M.; MACÍAS, D.; MEJUTO, J. Estimaciones científicas de los desembarcos de espécies asociadas realizados por La flota española de palangre de superfície em 1997 y 1998 Collect. Vol. Sci. Pap. ICCAT., v. 51, p. 1882-1893. 2000.

CERVIGÓN, F.; CIPRIANI R.; FISCHER, W.; GARIBALDI, L.; HENDRICKX M.; LEMUS, A. J.; MÁRQUEZ, R.; POUTIERS, J. M.; ROBAINA, G.; RODRIQUEZ, B. Fichas FAO de identificación de especies para los fines de la pesca. Guía de campo de las especies comerciales marinas y de aquas salobres de la costa septentrional de Sur América. FAO, Rome, 513 p. 1992

COX, W. M.; REID, E. E. The chemical composition of oil of Ruvettus pretiosus, the "castor oil fish". J. Am. Chem. Soc., v. 54, p. 220-229, 1932.

ELBARAASI, H.; ELMARIAMI, M.; ELMEGHRABI, M.; OMAR, S. First record of oilfish, Ruvettus pretiosus (Actinopterygii, Gempylidae), off the coast of Benghazi, Libya (Southern Mediterranean). Acta Ichthyol. Piscat. v. 37, p. 67-69. 2007.

FIGUEIREDO, J. L.; MENEZES, N. A. Manual de Peixes Marinhos do Sudeste do Brasil. VI. Teleostei (5). São Paulo: Museu de Zoologia da Universidade de São Paulo, 2000. 116 p.

LESSA, R.; VASKE-JR. T. A ictiofauna com ênfase aos peixes-voadores (Exocoetidae). In: VIANA D.; HAZIN F.; CARVAlho M. A. (Eds.) O Arquipélago de São Pedro e São Paulo: 10 anos de Estação Científica. v.1, p. 228-224. 2009. Available at 〈https://www.mar.mil.br/secirm/publicacao/arquipe.pdf〉 Accessed: January 2011.

LING, K. H.; CHEUNG, C. W.; CHENG, S. W.; CHENG, L.; LI, S.; NICHOLS, P. D.; WARD, R. D.; GRAHAM, A.; BUT, P. P. Rapid detection of oilfish and escolar in fish steaks: A tool to prevent keriorrhea episodes. Food Chem., v. 110, p. 538-546. 2008. doi:10.1016/j. foodchem.2008.02.066

LORENZO, J. M.; PAJUELO, J. G. Biology of a deep benthopelagic fish, roudi escolar Promethichthys prometheus (Gempylidae), off the Canary islands. Fish. Bull., v. 97, p. 92-99. 1999.

MEJUTO, J.; GARCÍA-CORTÉS, B.; DE LA SERNA, J. M.

Preliminary scientific estimations of by-catches landed by the Spanish surface longline fleet in 1999 in the Atlantic Ocean and Mediterranean Sea. Sci Collect. Vol.. Pap. ICCAT., v. 54, p. 1150-1163. 2002.

NAKAMURA, I. Gempylidae Escolares. In: FISCHER, W.; KRUPP, F.; SCHNEIDER, W.; SOMMER, C.; CARPENTER, K. E.; NIEM, V. (Ed.). Guia FAO para Identificación de Especies para lo Fines de la Pesca. Pacifico Centro-Oriental. Rome: FAO, 1995. v. 3, p. 1106-1113.

NAKAMURA, I.; PARIN, N. V. Snake mackerels and cutlassfishes of the world (families Gempylidae and Trichiuridae). An annotated and illustrated catalogue of the snake mackerels, snoeks, escolars, gemfishes, sackfishes, domine, oilfish, cutlassfishes, scabbardfishes, hairtails, and frostfishes known to date. FAO fish. Synop., v. 15, p. 1-136, 1993.

NEVENZEL, J.C.; RODEGKER, W.; MEAD J.F. The lipids of Ruvettus pretiosus muscle and liver. Biochemistry, v. 4, p. 1589-1594, 1965.

NICHOLS, P.D.; MOONEY, B.D.; ELLIOTT, N.G. Unusually high levels of non-saponifiable lipids in the fishes escolar and rudderfish, identification by gas and thin-layer chromatography. J. Chromatogr., A., v. 936, p. 183-191. 2001 .

OCHIAI, Y.; WATABE, S.; HASHIMOTO, K.; NARITA, H.; UKISHIMA, Y.; NARA, M. Biochemical identification of two Gempylid fishes causative of a food poisoning. Bull. Jpn. Soc. Sci. Fish., v. 50, p. 721-725. 1984.

PAKHORUKOV, N. P.; BOLTACHEV, A. R. On the Distribution and Behavior of the Oilfish Ruvettus pretiosus (Gempylidae) over Seamounts. J. Ichthyol., v. 41, p. 755-760. 2001.

PINKAS, L.; OLIPHANT, M. S.; IVERSON, I. L. K. Food habits of albacore, bluefin tuna, and bonito in California waters. Calif. Fish. Game., v. 152, p. 1-105. 1971.

RUIZ-GUTIERREZ, V. R.; ZARZA, M. C. P.; MURIANA, F. J. G.; BRAVO, L. Lipid and fatty acid composition of muscle and internal organs from Ruvettus pretiosus. J. Fish. Biol., v. 50, p. 1353-1357. 1997. doi: 10.1111/j.1095-8649.1997.tb01658.x

SATO, Y.; TSUCHIYA, Y. Lipids of Ruvettus pretiosus. I. Composition of alcohols and fatty acids. Tohoku J. Agric. Res., v. 20, p. 89-95. 1969.

SHADBOLT C.; KIRK, M.; ROCHE P. Diarrhoea associated with consumption of escolar (rudderfish). Communicable Diseases Intelligence, v. 26, p. 436438, 2002.

UYENO, T.; MATUSUURA, K.; FUJII, E. Fishes trawled off Suriname and French Guiana. Japan Marine Fishery Resource Research Center. 1983. 519 p.

VASILAKOPOULOS, P.; PAVLIDIS, M.; TSERPES, G. On the diet and reproduction of the oilfish ruvettus pretiosus (Perciformes: Gempylidae) in the eastern Mediterranean. J. Mar. Biol. Ass. UK., v. 91, n. 4, p. 873-881. 2011.

VASKE JR., T.; HAZIN, F. H. V.; LESSA, R. P. Pesca e Hábitos Alimentares do peixe-rei, Elagatis bipinnulata (Quoy and Gaimard, 1825) (Pisces: Carangidae) no Arquipélago de São Pedro e São Paulo, Brasil. Arq. Cienc. Mar., v. 39, p. 61-65, 2006. 
VASKE JR., T.; VOOREN, C. M.; LESSA, R. P. Feeding habits of four species of Istiophoridae (Pisces: Perciformes) from northeastern Brazil. Environ. Biol. Fishes, v. 70, p. 293-304, 2004.

VASKE JR., T.; VOOREN, C. M.; LESSA, R. P. Feeding strategy of yellowfin tuna (Thunnus albacares) and wahoo (Acanthocybium solandri) in the Saint Peter and Saint Paul Archipelago, Brazil. Bol. Inst. Pesca., São Paulo, v. 29, p. 173-181, 2003.

VIANA, D. L.; HAZIN, F. H. V.; NUNES, D.; CARVALHO, F.; VÉRAS, D.; TRAVASSOS, P. Wahoo Acanthocybium solandri Fishery in the Vicinity of Saint Peter and Saint Paul Archipelago, Brazil, from 1998 to 2006. Collect. Vol. Sci. Pap. ICCAT., v. 62, p. 16621670, 2008 .
WEIDNER, D. M.; AROCHA, F. World swordfish fisheries: an analysis of swordfish fisheries, market trends and trade patterns. v. IV, part A2b: Brazil. NOAA Tech. Memo, NMFS-F/SPO, v. 35, p. 237-628. 1999.

(Manuscript received 26 May 2011; revised 30 August 2011; accepted 12 September 2011) 